ACTA MYCOLOGICA

Vol. 41 (1): 7-10

2006
Dedicated to Professor Alina Skirgietto

on the occasion of her ninety fifth birthday

\title{
Urocystis skirgielloi, a new graminicolus smut fungus infecting Heteropogon contortus in India
}

\author{
MARCIN PIĄTEK \\ Department of Mycology, W. Szafer Institute of Botany, Polish Academy of Sciences, \\ Lubicz 46, PL 31512 Kraków, mpiatek@ib pan.krakow.pl
}

Piąt ek M.: Urocystis skirgielloi, a new graminicolus smut fungus infecting Heteropogon contortus in India. Acta Mycol. 41(1): 7 10, 2006.

Urocystis skirgielloi M. Piątek sp. nov. is described and illustrated on the basis of infected leaves of Heteropogon contortus (L.) Roem. \& Schult. collected in India. This is the first Urocystis species on the grass genus Heteropogon as well as on any grass genera belonging to the subtribe Anthistiriinae of the tribe Andropogoneae (Poaceae).

Key words: Urocystis, Urocystaceae, Urocystales, Ustilaginomycetes, India, Asia

\section{INTRODUCTION}

In respect to smut fungi, India is one of the best-explored countries in the Asiatic mainland thanks to such giants of Indian taxonomy as B. B. Mundkur, M. J. Thirumalachar, M. S. Pavgi, and many others, whose research has been supplemented by excellent works of K. Vánky, a Hungarian smut taxonomist. However, most reports, especially those published in regional Indian journals, are scattered in a number of papers that are often not easily accessible to smut taxonomists. A monograph study of smut fungi of India would be enthusiastically welcomed by the world's scientific community. Although well studied, India is still a paradise for mycologists, and new smut fungi are described from the area nearly every year. Another new species was found in unidentified materials obtained from the IMI herbarium, infecting leaves of Heteropogon contortus (L.) Roem. \& Schult., in Kashmir. It belongs to the genus Urocystis Rabenh. ex Fuckel, and is described and illustrated below.

Measurements of spores were taken by standard light microscopy (LM) in lactophenol heated to the boiling point and then cooled. The sizes given below are the means of 30 measurements of spore balls, spores and sterile cells. The SEM studies proceeded as described by Piątek et al. (2005).

It is great pleasure to dedicate this fungus to Professor Alina Skirgiełł, at the occasion of her 95 birthday. It is tribute to her many-sided mycological activity and arranging the professional mycological studies in Poland. 


\section{TAXONOMY}

Urocystis skirgielloi M. Piątek, sp. nov. (Figs 1-5)

Typus in matrice Heteropogon contortus (L.) Roem. \& Schult., INDIA, Kashmir, Mamal, 18 Oct. 1964, V. R. Pandotra (holotypus: IMI 121487!).

Sori in foliis, primo epidermide obtectas, deinde rupturas. Glomeruli sporarum globosi, subglobosi, ellipsoidales vel elongati, (20-)25-35 $\times(17-) 20-25(-30) \mu \mathrm{m}$, e sporis 1 - 4(-7) composite $(1-7,8 \%, 2-32,2 \%, 3-35,6 \%, 4-20,0 \%, 5-2,2 \%, 6$ $0,5 \%, 7-1,7 \%$ ), cellulis sterilibus complete circumdati, raro incomplete circumdati. Sporae globosae, subglobosae, ellipsoidales vel parum irregulars, olivaceobrunneae vel rubrobrunneae, (11-)12-14(-16) $\times$ 9-12(-13) $\mu \mathrm{m}$, levi. Cellulae steriles globosae, subglobosae, ellipsoidales vel irregulares, plerumque cum lateribus contactis deplanatis, flavae, (5-)6-11 × (4-)5-8(-9) $\mu \mathrm{m}$, pariete aequali, $1 \mu \mathrm{m}$ crasso, levi.

Sori in the leaves, forming long, confluent striae between the veins, at first greyish, covered by epidermis which ruptures longitudinally at maturity disclosing the blackish, powdery mass of spore balls, finally the leaf blade becomes twisted. - Spore balls globose, subglobose, ellipsoidal or elongated, (20-)25-35 × (17-)20-25(-30) $\mu \mathrm{m}$,

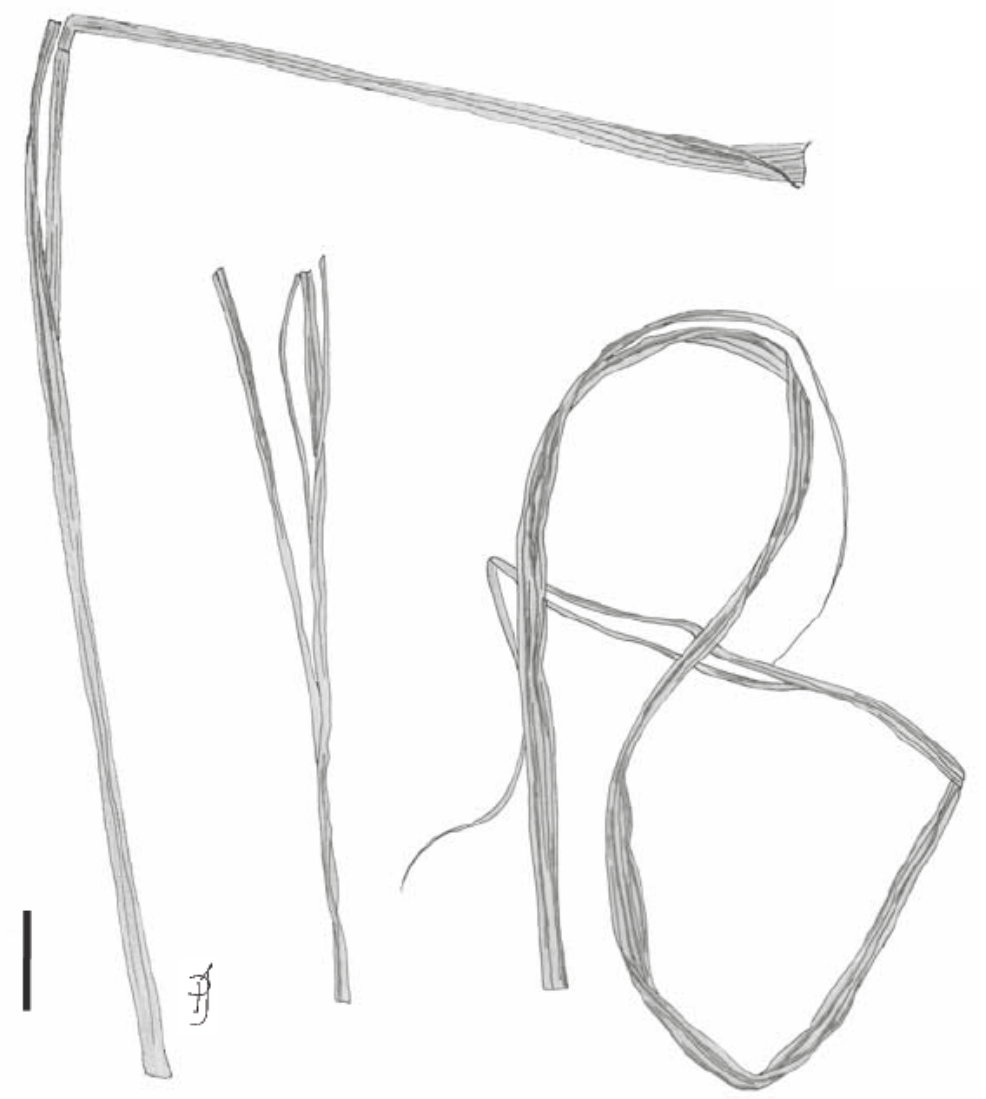

Fig. 1. Sori of Urocystis skirgielloi M. Piątek sp. nov. in the leaves of Heteropogon contortus (L.) Roem. \& Schult. (holotype: IMI 121487). Bar $=1 \mathrm{~cm}$. 
composed of 1-4(-7) central spores $(1-7.8 \%, 2-32.2 \%, 3-35.6 \%, 4-20.0 \%$, $5-2.2 \%, 6-0.5 \%, 7-1.7 \%$ ), surrounded by usually continuous layer of sterile cells, rarely the layer is not complete. - Spores globose, subglobose, ellipsoidal or slightly irregular, olive-brown or reddish-brown, (11-)12-14(-16) $\times 9-12(-13) \mu \mathrm{m}$, smooth in LM and SEM. - Sterile cells globose, subglobose, ellipsoidal or irregular, usually with flattened contact sides, yellowish, (5-)6-11 × (4-)5-8(-9) $\mu \mathrm{m}$, wall ca $1 \mu \mathrm{m}$ thick, smooth in LM and SEM.

Host and distribution. On Poaceae: Heteropogon contortus (L.) Roem. \& Schult.; India, Asia. Known only from the type locality.

Urocystis skirgielloi is the first species of Urocystis on the genus Heteropogon Pers. (Poaceae). This is a small grass genus, belonging to the subtribe Anthistiriinae of the tribe Andropogoneae (Clayton, Renvoize 1986), with six species occurring mostly in tropical and subtropical areas. Heteropogon contortus, which is the host plant of $U$. skirgielloi, is the most common member of the genus, widely distributed in tropical, subtropical and warm-temperate regions of Africa, Asia, Europe, North and South America, and Australia (Clayton et al. 2006). The host plant in the type collection is sterile and does not contain any inflorescence. The comparison of this material with the specimens of Heteropogon contortus preserved in the phanerogamic herbarium of the W. Szafer Institute of Botany in Kraków (KRAM) shows that they are morphologically similar.

Vánky (2000) revised smut fungi infecting Heteropogon and recognized eight species. However, all of them are completely different from Urocystis skirgielloi as they belong to the genus Sporisorium Ehrenb. ex Link, characterized by sori with peridium and columellae, spores usually arranged in spore-balls, and the presence or absence of sterile cells. All Sporisorium species known on Heteropogon produce sori in inflorescences of host plants. Urocystis skirgielloi has also no comparable species on other grasses closely related to Heteropogon. Of the 12 genera included in the subtribe Anthistiriinae by Clayton and Renvoize (1986), no Urocystis species had been described previously.

Acknowledgements. I am grateful to my wife Dr. Jolanta Piątek (Kraków, Poland) for her illustrations, to the Curator of IMI for the loan of the specimen of the new Urocystis species, and to Anna Latkiewicz (Kraków, Poland) for her assistance with SEM pictures. This study was supported by the Polish Ministry of Education and Science for the years 2005 2008, grant no. 2 P04G 01928.

\section{REFERENCES}

Clayton W. D., Renvoize S. A. 1986. Genera Graminum. Grasses of the world. Kew Bull., Additional Series 13: 1389.

Clayton W. D., Harman K. T., Williamson H. 2006. World Grass Species: Descriptions, Identifi cation, and Information Retrieval. http://www.kew.org/data/grasses db.html [accessed 20 February 2006].

Piątek M., Ruszkiewicz Michalska M., Mułenko W. 2005. Catalogue of Polish smut fungi, with notes on four species of Anthracoidea. Polish Bot. J. 50(1): 1937.

Vánky K. 2000. Taxonomical studies on Ustilaginales. XX. Mycotaxon 74 (1): 161215. 
Urocystis skirgielloi, nowy gatunek głowni porażający Heteropogon contortus w Indiach

\section{Streszczenie}

W pracy opisano i zilustrowano nowy gatunek głowni, Urocystis skirgielloi M. Piątek sp. nov., porażający liście Heteropogon contortus (L.) Roem. \& Schult. w Indiach. Jest to pierwszy gatunek z rodzaju Urocystis stwierdzony na trawach z rodzaju Heteropogon jak również na 11 pokrewnych rodzajach traw należących do podplemienia Anthistiriinae i plemienia Andropo goneae (Poaceae). 